\title{
EFFECT OF SEASONAI VARIATIONS ON THE HISTOLOGICAL STRUCTURES OF GONADS IN OREOCHROMIS NILOTICUS (TILAPIA NILOTICA)
}

\author{
Lashen Samah, Abd-Elmaksoud Ahmed and Marel Hany \\ Department of Mansoura Unlversity
}

\begin{abstract}
The morphological characteristics of the testes and the ovary of the Nile tilapia Oreochromis niloticus) are presented. Testiculor structure and spermatogenesis are described using histotogical techniques. The tesles consist of capsule, seminiferous lobules (contain spenratogenic cell. Sertoli cell), interstitial tissue (leydig cell and duct system. The coexistence in the testlcular lobules of spermatozoa and spermatogenic cells indicates that this species is able to perform continuous reproduction. Seasonal trend was notlced in the number of the spermatogenic cell produced over a year periad. The ovarian structure is also described using histological techniques. The ovary conslst of capsule and ovarian follicles (chromatin-nucleolus, perinucleolus, cortical alveolar, vitellogenic and mature). Each follicle consists of oocyte and surrounding structure (follicular cell and zona radiatal. Seasonal trend was noticed in the type of predominant follicles present over a year period.
\end{abstract}

Key wond: Oreochromis nlloticus, Nile tillapia, spermatogenic cell, Sertoli cell, leydig cell ovarlan folliçles, follicular cell.

\section{INTRODUCTION}

Tilaplas are among the most important warm water fishes used for aquaculture production and originate from Africa and the Middle East (Fryer and Des, 1972).

In all vertebrates, from fish to mammals. the testis is composed of two maln compartments. the tubular and the intertubular (or interstitlal) compartment (Schulz et al., 2009). The tubular compartment comprises the seminiferous eplthellum that contains only two cell types. the somauc Sertoll cells and the germ cells (spermatogenic cell). which are found at different stages of development (Matta et al. 2002). The tesucular lobule (or tubule) is surrouned by a tuniea propra. conslsts of basal lamina and perltubular myold cells (Schulz et al., 2009). The intertubular compartment contains stcroldogenic Leydig cells, blood/lymphauc vessels, macrophages. mast cells. neural and connective tissue cells. The latter being continuous with the tunlca albuginea (Dougbag et al., 1988a: Grler. 1993; Le Gac and Lolr, 1999; Koullab et al., 2002; Nobrega and guaglo-Grasslotto. 2007). The testicular lobules (or tubules) empty in the efferent duct system that con- 
nects these lobules to the deferent duet withIn the central portion of the testlcular parenchyma. The testlcular lobules are lined internally with Sertols cells, whose eytoplasmlc processes surround the spermatogonia and spermatocytes, forming isogente cysts. Durng spermatogenesis, these cysts flll the entire width of the lobule. preventing the appearance of the typical central lumen untll they open. when the mature germinal cells are released and form a lumen which anastomoses with the maln spermauc ducts (Le Gac and Lolr, 1899).

Tunica propria conslsts of basal lainina and peritubular myold cells (Schulz et al., 2009). Pentubular myoid cells show falrly good proliferation actlulty in Nile tllaplas. Perhaps the higher plasticity of this cell type in relation to its capacity to stretch in the tubular wall could influence its mitotic behavior (Schule et al., 2008).

Sertoll cells are always located on the basal lamina that llinits the testicular lobules. which separates them from the interstutal compartment. At the beginning of spermatogenesls, aggregates of Sertoll eells assoclated with primary spermatogonla are observed at the end of the lobule. At this time. Sertoll cells have a euchromatic and pleomorphic nucleus with a nucleolus, and a elear cytoplasm with traces of smooth endoplasmic reuculum and a fcw mitochondria with clear matrixes (Sabat et al., 2000).

Spermatogenests is a developmental process during whtch a small number of diploid sperrnatogonlal stem cells ( primary spermatogonla. secondary spermatogonla. primary spermatoeytes. secondary spermatocytes and spermatide) produee a large number of highly differentlated spermatozoa carrying a haploid. recombined genome (Schulx et al., 2008). Histologleally, these ean be identified as follow:

Primary spermatogonla: These cells are large, spherieal to oval in shape. The nucleus is large, sphencal. eentrally located and has prominent nueleolus (Dougbag et al., 1988a). Secondary spermatogonla: These cells are nearly similar to the primary spermatogonia but smaller in size and are found in groups forming cysts of variable numbers. The indivdual cells in a cyst have in general similar morphological appearance. The nucleus occupies most of the eell and it is smaller and deeper in stain than that of the primary spermatogonia (Dougbag et al., 1988a). Primary sperriatocytes: These cells form large cysts with prominent nuclei occupying most of the cells. Their nuclei havc no clear boundaries. The darkly stained chromatin materals are found In the form of clumped granules irregularly dlstributed in the entre cell (Dougbag et a.. 1888a). Secondary spermatocytes: They are found in cysts and have prominent darkly stained nuclel. These nuclcl are slightly irregular in shape and have clumped chromatin with no clear nucleoll (Dougbag et al., 1988a). Spermatid: in general these cells are simllar to the secondary spermatocytes but with small size. The chromatin is homogenous and apparently forms one clump (Dougbag et al. 1988a). Spermatozoa: They appear frotly In cysts after which they are released Into the tubular lumen. The sperm head appears as darkly stalned spherical body containing eccentric pale spot. Mature sperms are usually 
found within the efferent ducts and the main sperm duct (Dougbag et al., 1988a).

The Interstitial compartment comprises Leydig cells, blood/lymphatic vessels, macrophages, mast cells. neural and connective tissue eells (Dougbag et al., 1988a; Grier 1993; Le Gac and Lolr, 1999; Koullish et al., 2002; Nobrega and guagio-Grassiotto, 2007). The Leydig cells arc polyhedral in shape and have spherical darkly stained nuclel with prominent nucleolus and vaeuolated cytoplasm after H\&E stain (Dougbag, 1988a).

The efferent ducts are formed by modifled Sertoli cells (Grier et al., 1980; Grier, 1981: Selman and Wallace, 1986). However. the epithellal cells of the efferent duets are morphologieally very different from Sertoli eells that forn germinal cysts (Porawgkd et al., 1997).

The vertebrate ovary is an aggregation of developing follicles enmeshed in a vascular stroma of loose connective tussue and enclosed within an envelope of gonadal epithellum. The stroma consists of collagenous, elastic, and reticular nbers and becomes greatly distended as the follieles enlarge. Only in a spent ovary when the stroma is collapsed, is It easily seen.

The ovary has eonnectlve tissue lamellae (ovigerous lamellae) projecting from the tunica albuginea into the interior of the ovary. These lamellae contain oogonla and oocytes in varous stages of development whlch are in random arrangments (Mousa, 1988). Generally, four princlpal stages of oocyte development as out lined below have been described in several teleosts (Selman and Wallace, 1989). Chromatin-nucleolus stage, Perinucleolus stage, cortical alveolus stage. Vitellogenic stage and Maturation stage.

Chromatin-nucleolus phase. the oocyte is small with deeply basophilie ooplasm and the nucleus oecuples the greater part of the folltele. The nueleus of the oocyte is generally spherical with multiple nueleoll in a pernuclear position adjaeent to the inner layer of nuclear envelope (Guraya, 1986). Perinueleolus phase, the nucleus cnlarges to form the germinal vesicle and the nuclear membrane becomes undulating. The oocyte has additionally several nueleoll that arrange at the periphery of the germinal vesicle. The oocyte is surrounded by a single layer of flattened follieular cells (Selman and Wallace, 1989). Cortical alveolus stage, this stage is charaeterzed by the inltial appearanee of three components: cortlcal alveoll, zona pelluelda (radlate), and lipld. The oocytc is surrounded by cuboldal follicular cell (Begovac and Wallace. 1988: Selman, Wallace and Player, 1991). Vitellogenic stage. the enlargement of the oocyte takes place during vitellogenesis is due largely to an accumulation of yolk protein precursors (Begovac and Wallace, 1988). At this stage, the yolk sphere Inerease in stze whlle the cortical alveoll and lipid are displaced to the peripheral ooplasm. The oocyte is surrounded by columnar follicular cell (Begovac and Wallace, 1088). Mature stage (rpe stage), this stage is characterized by the enlargement of both cortical alveoll and yolk granules. The follicular eells are cuboldal or low cuboldal Wallace and Selman, 1981; Nagahama. 1983; KJesbu et al., 1998; Gothilf et al., 1997). 
Marked seasonal variations are observed in the dlameter and the frequency of these follicles in general, the follicles exhlbited larger diameter during summer and smaller at winter. In summer the majority of the follicles in ovary are maturing follicles while in winter the majority are immature and no mature follicle are observed. The atretic follicles are observed throughout the year with a sllght decrease in winter. In summer, the stroma is reduced by expansion of the developing follicles (Dougbag et al., 1988b, d).

\section{MATERIAL AND METHODS}

Samples (120 sexually mature Nile tlapla) were obtalned from River Nile In Met Amer city collected at every month from January to December 2008. Fish were cut ventrally from the genttal papillae to the base of the pectoral nn using a scalpel. A window on the lateral side was opened and the viscera were removed leaving gonads. The collected samples were routinely flxed for light microscope.

Small pleces $\left(0.5-i \mathrm{~cm}^{3}\right)$ of the gonads were fixed in both Bouln's and $10 \%$ neutral buffered formalin solutions for $12 \mathrm{hr}$ and 72 $\mathrm{hr}$ respectlvely. The Bouln fixed samples were extensively washed in $70 \%$ ethanol ( $3 \times 24 \mathrm{hr}$ ) to get rid of the fixatlve belore the subsequent steps of tlssue processing. Formalin-flxed materlals were washed for $2 \mathrm{hr}$ under the running tap water before ethanol immersion. The tissue samples were dehydrated in graded series of ethanol (80\%. 95\% and absolute). cleared in xylene and embedded in paraffin wax. Five micron thick sections were cut by microtome and mounted on glass slides for ordinary stajn. The histological processing and preparatlon of the gonadal slides were carred out according to the standard histologlcal technlques (Patkl et al., 1989; Lal, 2001).

\section{RESULT}

\section{Testlcular structure :}

The parenchyma of the Nile tllapla testls was surrounded by a thin white fibrous capsule and is divlded into clear seminlferous lobules, efferent and defferent duct (Fig. la). The tunlca albuginea is formed predominantly of collagen flbers, rew elastic nbers and smooth muscle cells. Numerous fibrocyles are also recognilzed within these fbrous components. They were continuous with thin inconspicuous connecuve tissue trabeculae (septa).

Most of the testicular tissue was made up of the seminiferous lobules, where the spermalozoa are formed. These lobules are baslcally two-ended loops, with one end opening into the efferent duct. The seminiferous lobules were arranged in the form of cystes were enclosed by a distinct lamina proprla (basal lamina and myold cell) and contained two disunct cell types; Sertoll cells and spermatogenic cells (Fig, 1b).

The Sertoll cells were easlly Identifled. They were large Irregular whth lattened elongated dense nuclei that were often deeply infolded or invaginated and contalned large central nueleoll. They were located located In contact with the basal lamina and their cytoplasmic proeesses shared in formation of germinal cysts and were extending between the spermatogonla (Fig. IC).

The Spermatogenic cells were differentlated into four morphologically different groups. 
i.e., spematogonia, spermatocytes, spematids, and spematozoa.

The undifferentlated spermatogonla were a single. large spherical cell (dlameter10.60 \pm $0.21 \mu \mathrm{m})$ with clear centrally located nucleus (FIg. Ic). They were not found inslde cyst and mostly secn under connective tlssue capsule close to Sertoll cells. They were mainly located at the periphery of seminlferous lobules beside eyst which contaln other spermatogenlc eells.

The primary spermatogonia with a mean dlameter $8.87 \pm 0.298 \mu \mathrm{m}$. Found in pairs or small groups. They had cytoplasm and $a$ large prominent nucleus. Occur Inside cysts (Fig. Ic).

The secondary spermatogonla were found in groups and are cneloscd In a cyst. Their mean diameter of $5.23 \pm 0.177 \mu \mathrm{m}$. The nucleus is spherical and central in location. The nucleus occupied most of ccll and cytoplasm was deeply stained (Fig. Id). In general the spermatogonla are predominant during winter reason.

The primary spermatocytes had a mean diameter of $4.80 \pm 0.130 \mu \mathrm{m}$. Thelr nuelel were spherical with deeply stained ehromatn (Fig. 1d).

The secondary spermatocytes had a mean dlameter $4.07 \pm 0.135 \mu \mathrm{m}$. They were eharacterlzed by thelr large nucled that were oecupying most of the cells. The nuclel that were surrounded with thin in of cytoplasm. They were found in large nests extcriding into the lobular lumen (Fig. le). Spermatocytes were predominant during autumn season.

The spematids had a mean dlameter of $2.70 \pm 0.119 \mathrm{\mu m}$. They had a sparse cytoplasm with spherical dense nuclei (F/g. 1d). Some cysts of spermatids ruptured and the spermatozoa released into the lobular lumen.

The spermatozoa had a mean dlameter of $1.93 \pm 0.117 \mu \mathrm{m}$. They were present in the lumen of testicular lobules, and were characterlzed by deeply stained rounded head whth very fne protoplasmlc tall that was barely visible under the light microscope. They eoncentrate in the lumen of seminlferous lobules after breaking through the cyst wall. They were eneountered all over the year ( $F / g$. Id).

The Interstitial cells (Leydig cells) were seen elther singly or in groups in the interlobular space. There were polygonal in shape, with ill -deninite cell boundaries and centrally located spherical nuclel (Fig. If).

The Sertoli cells appeared to be hypertrophied and remaln on the basement membrane. The basal lamina open and works as an efferent duct. That links system links the seminlferous tubules to the deferent duct (Fig. la). That stored and releases the spermatozoa Into eommon duct that leads to a genital pore. There were not aceessory glands. or seminal vesicle.

\section{Ovarlan structure :}

The ovaries were surrounded by a single layer germinal eplthellum. which ensphercs a thick tuniea albuglnea whieh consisted of a dense collagenous connective tissue with smooth muscle cell and also contalned 
retieular fibers and few fine elastic fibers (Fig. 2a). Ftve stages of ovarian follicles were Identified.

The chromatin-nucleolus stage had a very minute polygonal oocytes distributed in the ovary (diameter $31.17 \pm 1.42 \mu \mathrm{m}$ ). The nucleus was spherical the cytoplasm showed a strongly basophlllc zone around the nucleus. One or two nucleoll scatter towards center of the nueleus (Fig. 2b). A follicle layer in the wall of young oocyte is not distinguished. These follicles were common in winter and autumn seasons and less abundant during spring and summer seasons.

The perinucleolus stage had an oocytes were polygonal in shape and increase in size (d1ameter $126.93 \pm 4.66 \mu \mathrm{m}$ ). The cytoplasm was aeldophllle. The nucleus was spherlcal and contained an average of 8 basophllic nucleol arranged peripherally of nuclear membrane. The oocyte was surrounded by a simple layer of flattened squamous (diameter $1.47 \pm 0.133 \mu \mathrm{m})$. These follicles were common in winter and autumn seasons and less abundant during spring and summer seasons (Fig. 2c).

The eortlcal alveolar stage had an oocytes were charactenzed by increasing of its size (dtameter $366.67 \pm 11.57 \mu \mathrm{m}$ ) and thelr nucleui whleh became slightly basophille with increased number of nucleoll but. still adjacent to nuclear membrane. The ooplasm is basophillc and surrounded by a simple follicular epithellum which was made up low cuboldal cells (diameter $3.47 \pm 0.19 \mu \mathrm{m}$ ). Some minute vacuoles are located towards the outwards of cytoplasm (cortical alveoll) and appeared as large vacuoles around the nucleus (lipid vaeuole). The zona radiate was Arstly appeared between the follicular eells and oocytes (diameter $1.27 \pm 0.12 \mu \mathrm{m})$, and was PAS posituve layer. The ooplasm was PAS negative. These follicles were abundant during spring and summer, but decreased during autumn and rarely observed during winter Fig. 2d).

The vtellogenlc stage had an oocyte increased in size due to growth and accumulatuon of yolk granules in inner part of cytoplasm (diameter $538 \pm 20.34 \mu \mathrm{m}$ ). The oocyte became Irregular In shape. The nucleus became Irregular in shape and zona radiata layer increased in thickness. The yolk granulcs intermingled with lipid vesicles. The nucleus began to migrate to the animal pole. The follicular cells were cuboidal epithellal cells. The zona radiate beeame thicker (dlameter $1.47 \pm 0.133 \mu \mathrm{m})$. The follicular cell become tall cuboldal (dlameter $5.20 \pm 0.174 \mu \mathrm{m}$ ). These follieles were abundant during spring and summer, but decreased during autumn and rarely observed during winter (Fig. 2e).

The ripe stage (mature stage) had an ocyte was Irregular in shape. this ooeyte is the largest one (djameter $1346.93 \pm 29.83 \mu \mathrm{m}$ ). The nueleus migrate 1nto anlmal pole. The yolk enlarge form yolk sphere and follicular cell became low cuboldal (diameter $4 \pm$ $0.33 \mu \mathrm{m}$ ). Their ooplasm was charaeterized by being full of large yoik globules. The zona radiate showed its maximum thickness (diameter $6 \pm 0.33 \mu \mathrm{m}$ ) and gave PAS positive reaction. These follicles were common during spring season and few in summer but. rarely observed during autumn and winter (Flg. 2f). 


\section{DISCUSSION}

The present study demonstrated that the testls of Oreochromis nilotieus was covered by tunica albuginea. hundreds of smooth muscle cells and blood vessels, which send out septa to the Inner part of the organ, forming lobes that are flled with seminlferous lobules. The seminiferous lobules are composed of cysts, which are deîned by cytoplasmatic projecthons of Sertoll cells. The spermatogentc cells in each cyst are In a stage of development. Similar fìndinges were prevlously by Santos et a1. (2006) In Oligosarcus hepsetus.

The testleular lobules of Oreochromis n1loticus were surrounded by boundary cells. These finding were consistend with Marshall and Lofts (1956) in Labeo flsh. Lofts and Marshall (1957) in Esox Ish and Moser (1967) In S. Pauelspinis. On the other hand the lobules of other specles were surrounded by fusilorm shaped myold cells as a contractile element around the lobules Rosenblum et al. (1987), il bullhead eatish. I.nebulosus).

The present studies clarlfled that the Individual lobule contained many different germinal cysts and each eyst had the same spermatogenic stage. The germinal cysts were surrounded with the cytoplasmlc processes of the Sertoll cells that shared with very thin eollagen fibers in the formation of the wall of cysts. This resembled the results of Abraham et al. (1980) in A.dispar, Saad and Bullard (1967) In C.carplo, Arenas et al. (1995) in G.affinitg and Nakaght et al. (2003) in C. Macropomum.

The undifferentlated spermatogonla of the
Oreochromis niloticus were the largest cells and could be differentiated, in to two type: primary spermatogonita and secondary spermatogonla whlch were similar to each other but. the secondary spermatogonia were smaller in size. This result was supported by Gaber (2000) in Bagrus species.

Apparently the males of Oreochromis nilottcus are able to reproduce at any ume of the year, because of the presence of spermatogonla and spermatozoa inslde the seminiferous tubules all over the year. However. the reproduetive phase can be assoclated with the female ovarlan maturation perlod, aecording to Bantos et al. (1995).

The primary spermatoeytes were not the largest germ cells but, they were smaller than spermatogonla and slightly bigger than secondary spermatocytes. These flndings were simllar to those of Rlzkalla (1970) in C. Lazera. Rosenblum et al. (1887) in I.nebulosus, Iladou and Fishelson (1996) in eatfish, and Oteme et al. (1996) in African elarild catish and Heterobranehus longlfllis.

The secondary spermatocytes of the Oreochromis nllotlcus were characterized by their large dense nuclel that were oecupying most of the cells and were surrounded with a thin $\mathrm{rm}$ of cytoplasm. Numerous mitotlc divisions were seen in the primary spermatocytes. Both types of spermatocytes were found throughout the year, but they were abundant during the spring, summer and autumn seasons with inereased toward the spawning seasons.the aforementloned flndinges were in agreement with result of Nayyar and 8undoraraf (1970) In H. fossill, Rosenblum et al. (1987) in 
1.nebulosus and Gaber (2000) in Bagrus specles.

The spermatids of the Oreochromis nlloticus were smaller than the previous germ eells and appeared as small cells of indistinet outline with scanty cytoplasm and dense sphercal nuclcl. This finding was supported by Iadou and Fishelson (1.095) in P. aristotells, and Oteme et al. (1996) in H. loniflis.

The spermatozoa of the Oreochromls nllotcus were the smallest germ cell and charac. terzzed by deeply stalned rounded heads with very fine protoplasmic talls. They were present in the lumen of the testieular lobules without any arrangemcnt. These findings were in harmony with those of Rosenblum et al. (1987), Gaber (2000), Nakaghl et al. (2003) and Rutalsire ot al. (2003) in other fish. On the contrary, James (1946) found the spermatozoa of L.macroch'rus in compact masses.

The efferent duct system links the semintferous tubules to the defercnt duct. A number of authors agree that these efferent ducts are formed by modifled Sertoll cells (Grier ot al., 1980; Grier, 1981; Selman Wallace, 1986).

The ovary ol the Oreochromis niloticus was covered by tunica albuginea which consisted of dense collagenous connective tissue, elastic nbers and network of reticular nbers. The ovarlan wall was supported with smooth muscle cells. This result agreed with the result of Rizkalla (1970) In C. lazera. Yoaklm (1971) in S.shall. Khollaf et al. (1991) and Gaber (2000) in B. bayad.
Thic oocytes in the chromatin-nucleolus stage were small with deeply basophllic ooplasm and nuclel occupled the grealer part of the follicle. This stage corresponds to the prematuration pertod of Zakl et al. (1986) in Clarles garlepinus. Zakl and El-Gharabawy (1991) In Mugil capito, Aseem (1992, 1996) in Solea specles. Thcy were found throughout the year, but were common in the autumn and winter and less abundant during spring and summer.

The perinucleolus stage was eharacterized by increase of size in oocytes. The nucleoll increased in number and were mostly located toward the periphery of nuclear membrane. Durng this stage. the wall of the oocyte is eomposed of one thin layer of flattened follicu. lar cells. This result resembles that described by Abdo (1996) In Dicentrachus labrax, ElGahary (1996) in O. niloticus. Zakl et al. (1996) in Siganus rivulatus, Moustafa and El-Boray (1999) in Rhabdosargus hoffara.

The cortical alveolar stage had less basophulic and frothy ooplasm, they were found throughout the year, but were common in the autumn and winter and less abundant during spring and summer. This result was consistent with those of Ismall (1092) in C.lazera and Jirarach Brijunngam (2000) in Oreochromis niloticus.

The vitellogenic folllcles cytoplasm became actdophillc duo to the deposition of vitellogenin Into the oocytes whleh characterized by the appearance of the yolk granules. These granules appeared firstly at the perphery of ooplasm then aggregated to ward the center of the oocytes. This finding was simular to the 
result of Yoakdm (1971) in S.schall and Gaber (2000) in Bagrus specles. These vitellogenic follicles were decreased during autumn but, abundant during spring and summer in order to turn rapidly Into mature follıcles.

The mature or ripe folliclcs characterzed by migration of thelr nuclei toward the animal polc. with presence of large yolk globules. This finding was similar to the result of Yoakim (1971) in S.schall and Gaber (2000) in Bagrus species.

Fig. 1: testicular structure

a) General structure of testis of Nile ulapla showing tunlca albuglnea (TA), seminiferous lobulcs (curved arrow), septa (arrow), efferent duct(ED) and defferent duct (DD). H\&E (X 10 ).

b) Testus of Nile tulapia showing basal lamina (BL), primary spermatogonta (PSG), spermatde (SD) and spermatozoa (SZ). PAS (X40).

c) Transverse section of testus of Nile tllapla showng undlfferentiated spermatogonda (SG). primary spermatogonta (PSG) and Sertoli cells (arrow head). H\&E(X 100).

d) Testls of Nile tlapla showing seminiferous lobules contains undiffercntiated spermatogonla (SG), primary spermatogonla (PSG), secondary spennatogonla (SSG).. spermatozoa (SZ) and leydig cell (L). H\&E(X 100).

e) Testis of Nile tlapla showing undffferentlated spernatogonia (SG), primary spemato- gonla (PSG), primary spermalocytes (PSC). secondary spermatocytes(SSC), spermatozoa (SZ) and leydig cell (L). H\&E(X 100).

n) Transverse section of tests of Nile tilapla showing seminlferous lobules contains undifferentlated spermatogonia (arrow head). primary spermatogonta (PSG), secondary spermatogonla (SSG). spermatozoa (SZ) and leydtg cell (arrow). H\&E(X 100).

Fig. 2 : ovartan structure

a) General structure of ovary showing, tunica albuginea (TA), ovigerous lamellae (OL) contalns different stages of ovarian follicles (OF). $\mathrm{H} \& \mathrm{E}(\mathrm{X} 4)$.

b) Ovary of Nile tllapla showing, chromatine. nucleolus stage (CH). $\mathrm{H} \& \mathrm{E}(\mathrm{X} / 00)$.

c) ovary of Nile tilapla showing. pernucleolus folliele $(P)$ with follicular cell (arrow) , nuclcus (N). nucleolus (arrow head) and connec tlve tIssue septa (CT).H\&E(X40).

d) Ovary of Nile thapla showing, cortical. alveolar follicle(C) with cortical alveoll (arrow head), follicular cell (arrow), nucleus (N) and appear zona radlata (curved arrow). $\mathrm{H} \& \mathrm{E}(\mathrm{X} 100)$.

e) Ovary of Nile tilapla showing, vitellogenic stage (V) with cortical alveols (anrow head), follicular cell (arrow), cortical alveoli (arrow head) nucleus (N) and appear zona radiata (curved arrow) and yolk (M. H\&E (X100).

f) Ovary of Nile Ulapla showing. mature folltcle (M), and yolk sphere $M$ and connective tIssue septa (CT).H\&E(X40). 
Lashen Samah; et al...

Fig 1(a)

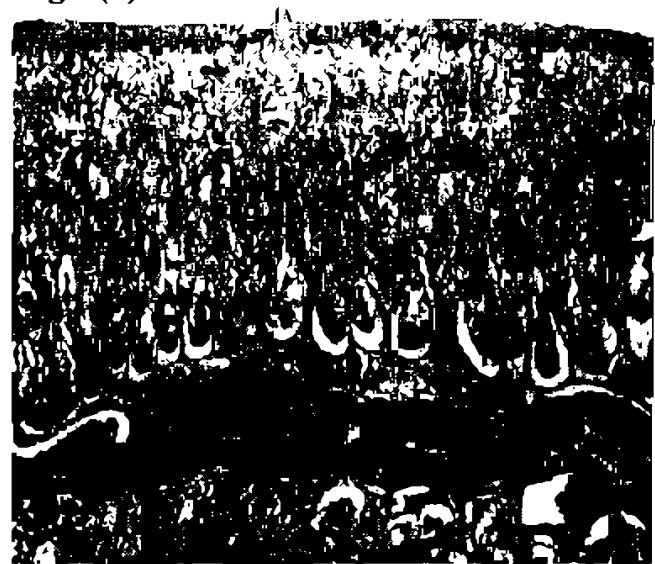

Fig 1(b)

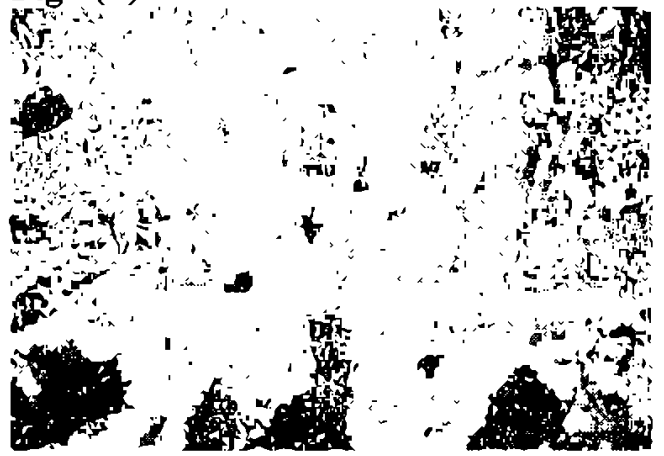

Fig 1(c)

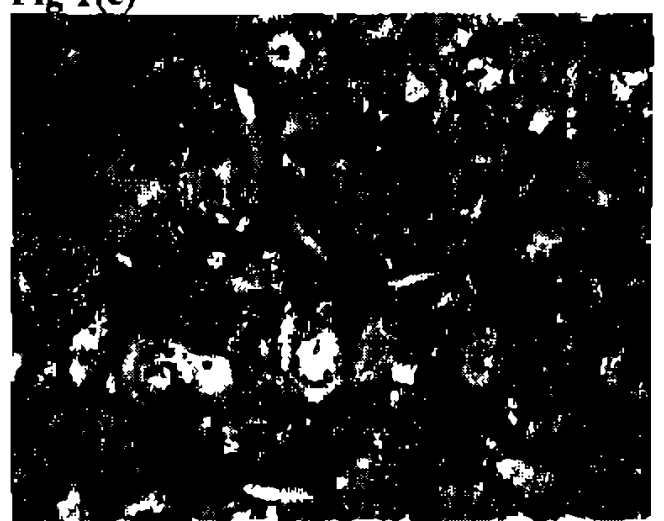

Fig 1(d)

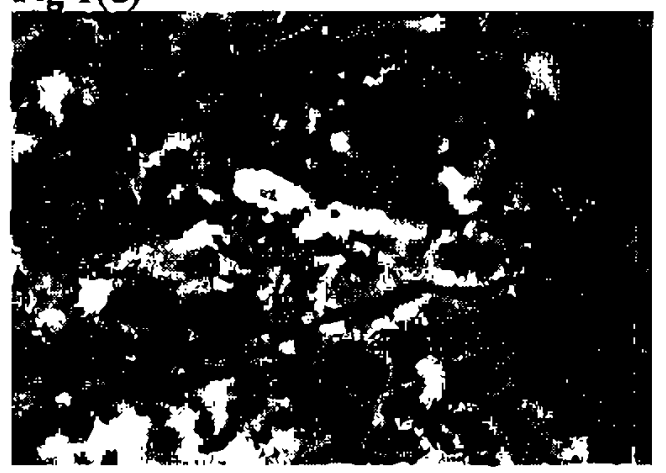

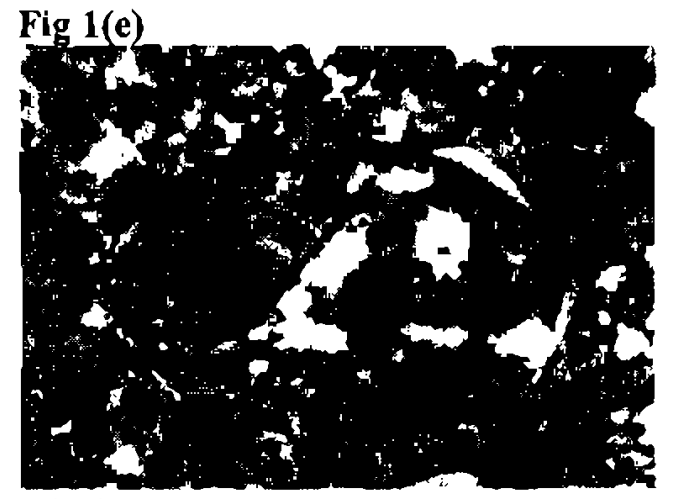

Fig 1(f)

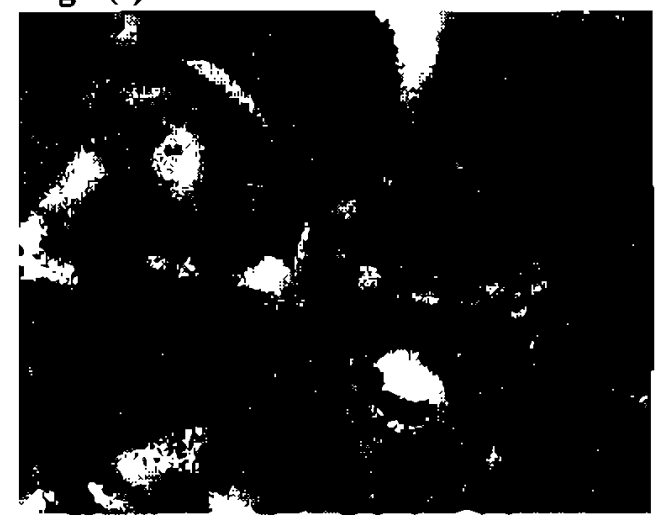

Mansoura, Vet. Med. J.

Vol. XI, No. 2, 2009 
Lashen Samah; et al...

Fig 2(a)

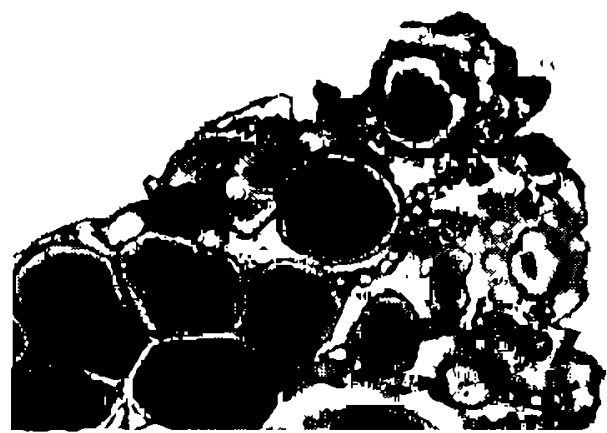

Fig 2(b)
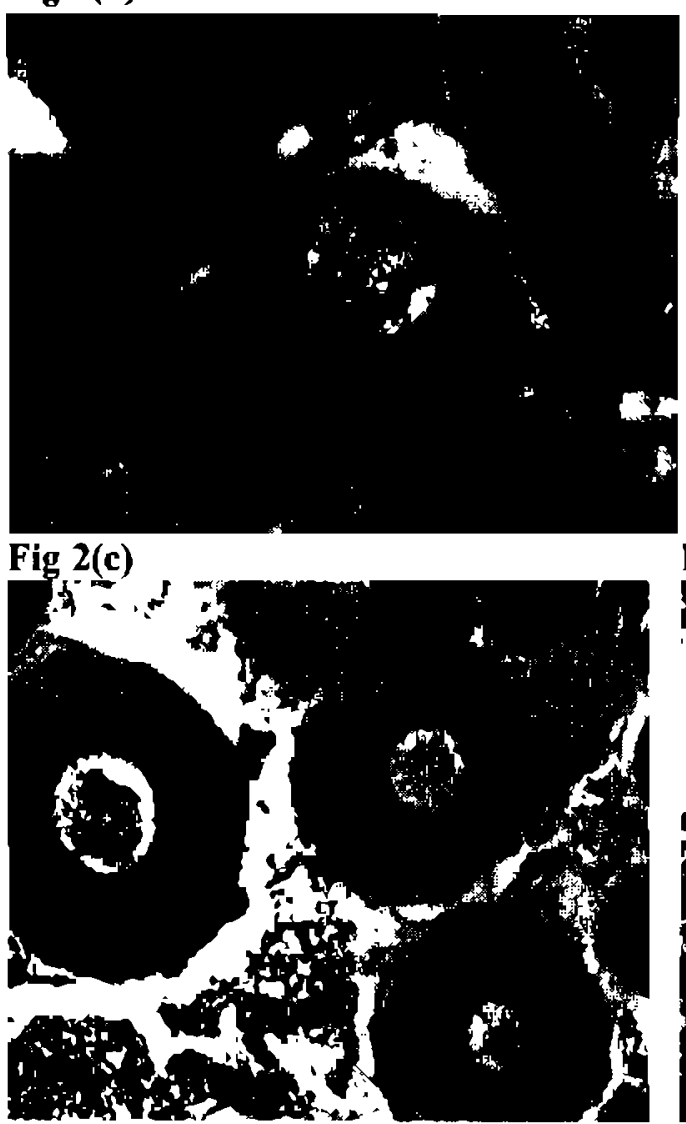

Fig 2(d)

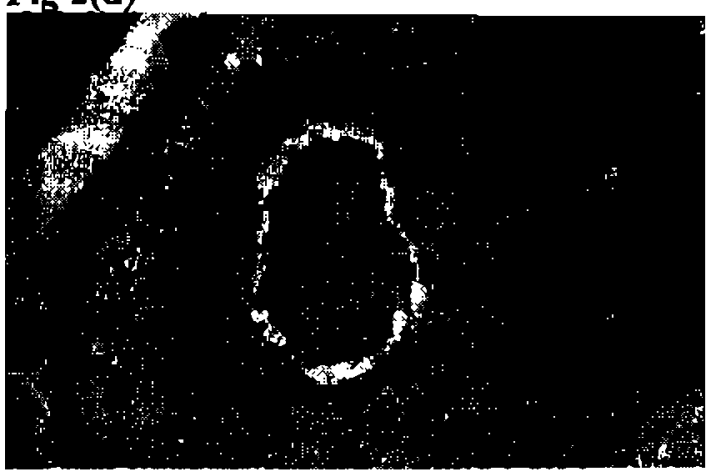

Mansoura, Vet. Med. J.

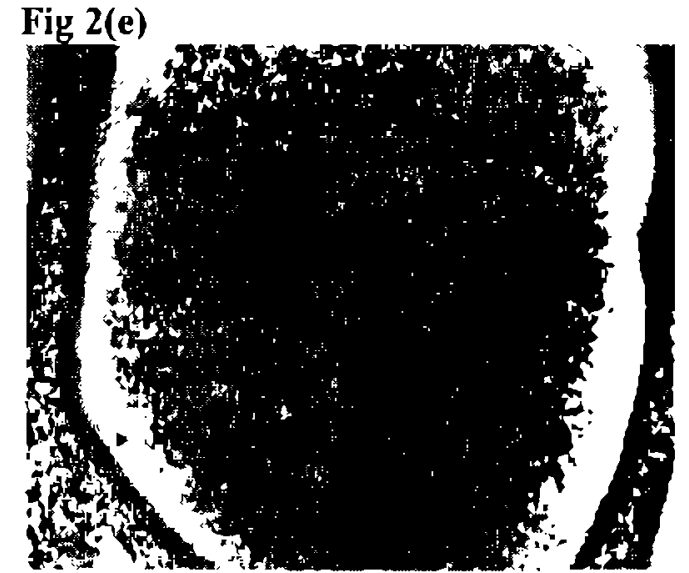

Fig 2(f)

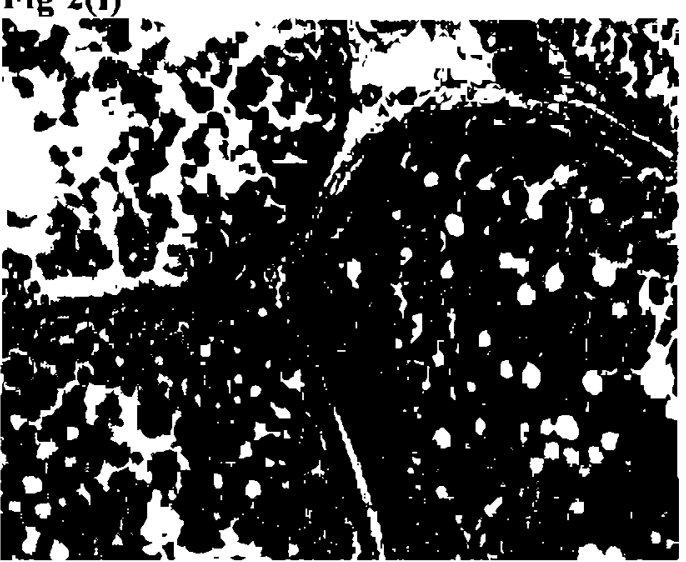

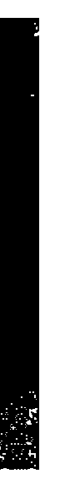




\section{REFERENCES}

Abdo, M. A. A (1906) : Reproductive blology and induced spawning of Dicentrachus Ladrax. Ph. D. Thesis, Faeulty of Science. Alexandra University, Alexandria. Egypt.

Abraham, M.; Ahamlm, E.: Tiblkz, H. and Golense, E. (1980) : The blood testis barrler In Aphanlus dispar (Telostei). Cell Tissue Res., 21 1: 207 -214.

Arenas, M. I.; Pralle, B.; Paz De Miguel, M. and Pantagua, R. (1995) : Cytoskeleton in Sertoll cells of Mosquito fish. Gambusia affinls holbrookl. Anat. Rec., 241: 225 - 234.

Assem. 6. (1992) : Rcproductive blology and physiology of one species of tamlly Sparidae in Mediterranean Sea. M. Sc. Thesis, Faculty of Scienice. Alexandria University. Alexandria. Egypt.

Arcem, 8. (1995) : Reproductlve physiology and Induced spawing of Solea specles. Ph. D. Thesis, Faculty of Sclence. Alexandria University. Alexandra, Egypt.

Begovac. P. S. and Wallace, R. A (1988) : Stages of oocyte development in the pipflsh. Syngnathus scovelli. J. Morph., 193:1139-1163.

Dougbag, A: EI-Gazzawy. E.; Kassem, A: El-Sheweml, S.; Abd El-Axlz. M. and Amln, M. (1988a) : Histologlcal studies on the testls of Trlapia niloticus. I. Basic structures. Alex. J. Vet. ScL, 4; $49-58$.

Dougbag, A: EJ-Gazzawy, E.; Kasgem.
A. El-Sheweml, S.: Ahd El-Azlz, $M$. and Amin, M. (1988b) : Histological and histochemical studles on the testus of Tilapla niloticus. II. Seasonal variations. Alex.J. Vet. Sci. 4: $59-69$.

Dougbag, A.; El-Gazzawy, E.; Kassem, A. El-Sheweml, S.; Abd El-Azlz, M. and Amln, M. (1988d): Histologlcal and histochemieal studics on the ovary of Tylapla niloticus. II. Seasonal variations.Alex. J. Vet. Scl. 4: $39 \cdot 48$

El-Gohary, N. M. A. (1996) : Ellect of temperature on the histology. histochemistry and blological activitles of the gonads of Oreoehromis niloticus. M. Sc. Thesis. Faculty of Sclence, Aun Shams University. Egypt.

Fryer, F. E. and Des, T. D. (1972) : The Clchlld Fishes of the Great Lakes of Arica: Their blology and evolution. Oliver and Boyd. (Ed.). Edinburgh.

Gaber, S. A. O. (2000) : Blological. Histologlcal and Histochemical studies on the Reproductive Organs and Pitultary gland of $\mathrm{Ba}$ grus docmac and Bagrus bayad in the Nile water. with spectal reference to the Uitrastructure of supporting tissues.Ph.D.Thesis. Faculty of Sclence. Zagazig Univenisty.

Gothilf, Y.: Meirl, 1.; Elizur, A and 20har. Y. (1997) : Preovulatory changes in the levels of three gonadotropin-releasing hormone-encoding messenger ribonuclelc acids (InRNAs), gonadotropin $\beta$-subunit mRNAs. plasma gonadotropln, and sterolds in the female glthead seabream. Sparus aurata. Btol. Reprod. 57:1145-1154. 
Grier, H. J. (1981) : Cellular organlzation of the testls and spermatogenesis in rishes. AM. Zool., $21: 345-357$.

Grier, H. J. (1993) : Comparatve organlzation of Sertoll cells ineluding the Sertoll cell barter. In: Russell LD, Griswold MD (eds) The Sertoll eell. Cache Ruver Press. Clearwater. FL. pp 704-739.

Grier, H. J.; Linton, J. R.; Leatherland, J. F. and Devalming, V. L. (1980) : Structural evidenee for two different testlcular types In teleost fishes. Amer. J. Anat, 159: 331 345 .

Guraya, S. S. (1986) : The eell and molecular biology of fish oogenesis. (Karger: Basel). In: G., West, Methods of assessing ovarlan de velopment in flshes. J. Mar. Freshwat. Res.. 11: $199-222$.

Hadou, K. F. L. and Flshelson, $L$. (1985) : Histology and cytology of testes of the catfish. Parasthuris anstotelis (Slluridae: Teleostell, from Greece. Jp. J. Ichthyol., 41 : $447-454$.

Ismail, R. S. (1982) : Physiologieal study on spawning in some flshes (Glorlas lazerd). M.V.Sc. Thesis. Anlmal physiology. Zagazig Untversity (Benlıa braneh).

James, M. (1946) : Histology of gonadal ehanges in the bluegili. Lepomis macrochirus. and largemouth bass. Huro salmoides. J. Morph..79:63- 92.

Jirarach Sirjunngami: Noppadon Kitana, I A.N. P. Callard and Kingkaew
Wattanasirmkit (2000) : Ultrastructural Changes in the Ovalian Folljeular Wall During Oocyte Growth in the Nile Tilapia. Oreoch. romis nilotleus Linn. The Natural History Joumal of Chulalongkom University 5(1): 21 . 30.

Khallaf, E. A: El-Saadany, M. M. and Authman, M. (1981) : Oogenesis of Bagrus bayad (Forsk.). J. Egypt. Ger. Soc. Zool., 4: I 4.

KJesbu, O. S.; Kryvl, H. and Norberg, B. (1996) : Oocyte size and structure in relation to blood plasma sterold hornones in Individually monitored. spawning Atlantie cod.J.Fish Blol., 49:1197-1215.

Koulish, S.: Kramer, C. R, and Grier, $H$. $J$. (2002) : Organization of the male gonad in a protogynous fish. Thalassoma bifasclatum (Teleostel: Labridae). J. Morphol. 254, 292311.

Lal, S. S. (2001) : "A Text Book of Practical Zoology Vertebrate". Seventh Revised Edition. 'Gangotri' Shivaj1 Road. Meerut-250002. Publ. Rastogl publleations: $138-148$.

Le Gac, F. and Lolr. M. (1899) : Male reproduetve system, fish. In: Knobll E, Neill JD (eds) Encyclopedla of reproduction, vol 3. Aeademlc Press, San Diego. pp 20-30:

Lofts, B. and Marshall, A. (1957) : Cyelical changes in the distribution of the testls Ilpids of a teleost flsh. Esox hicius. Quart. J. Mler. Scl. 98: $79-88$.

Marshall, A and Lofts, B. (1956) : The 
Leydig cell homoluge in certain teleost fishes Nalure. 177: 704 - 707.

Matta, S. L. P.: Vllela, D. A. R.; Godinho, H. P. and Franca, L. R. (2002) : The goltrogen 6-n-propyl-2-thiouracll (PTU) gdven durIng testls development Increases Sertoll and germ cell numbers per cyst in fish: the tllapla (Oreochromis niloticus] model. Endocrinology; J43: $970-978$.

Moser, G. (1967) : Seasonal histological changes in the gonads of Sebastodes paucisplnis Ayres, an ovoviviparous teleost (Family : Scorpaenidae). Ibld., 123:329 354.

Mouba. A. M. (1898) : Immunocytochemlcal and Histological studies on the reproductive endocrine glands of the Nile tllapia. Orcochromis niloticus (Teleostei. cichlidae). $J$. Egypt.Ger.soc.zooL، 27: 109 - 134.

Nagahama Y. (1883) : The functional morphology of teleost gonads. In WS Hoar. DJ Randall. EM Donaldson, eds. Fish physlology. Vol.9. part a. endocrine tissue and hormones. New York; academic press. pp.223-275.

Nakaghi, L. S. O.; Mltsuthd, D.; Santos, H. S. L.; Pacheco, M. R. and Ganeco, L. N. (2003) : Morphometry and morpholosy of nucleus of the Sertoll and interstitlal cells of the tambaqui Colossoma macropomum (Cuver. 1881) (Pisces: Characidac) durtng the reproductive cycle. Braz. J. BioL. 63

Nayyar, S. K. and SundararaJ, B. I. (1970) : Seasonal reproductive activity in the testes and seminal vesicles of the catish. Het- eopneustes fossills (Bloch). J. Morph. 130: $207-225$.

Nobrega, R. H. and Guaglo-Grasslotto, 1. (2007) : Morphofunctional changes in Leydig cells throughout the continuous spermatogenesis of the freshwater teleost flsh. Serrasalmus spllopleura (Characiformes, Characidae): an ultrastructural and enzyme study. Cell TIssue Res 329(2):3.39-349.

Oteme, Z. J.: Rodriguez, J. N.: Foungal, C. K: Hen, S. and Agnese, J. F. (1006) : Testicular structure, spermatogenesis and sperm cryopreservation in the African clarifd catflsh. Heterobranchus longillis iVaenclennes, 1840). Aquaculture Research, 31 : $805-813$.

Patrd, L. R.: Bhalchandra, B. L. and Jeevajl, I. H. (1989) : An Introduction to microtechnique. S. Chand \& Company, Ltd. Ram Nagar, New Delhi-110055. 28-78 pp.

Porawskd, M.; Wassemann, G. F. and Achaval, M. (1997) : Functional morphology of male gonad of kingfish. Rev. Bras. Blol.. 57: 151-159.

Rizkalla, W. (1070) : Studies on the gonads of the teleost Nile cathsh. Glorla lazera (C. and V.), with special reference to their endocrine ussuc. Acta Vetentnaria, 20:-1 - 12.

Rosenblum, P. M.: Pundy. J. and Callord. 1. P. (1987) : Gonadal morphology. enzyme hislochemistry and plasma sterold levels durIng the annual reproductivc cycle of male and fermale brown bullhead cathsh, Ictalurus nebulosus. J. FIsh. BIoL. 31: 325 - 341. 
Rutaisire, J.; Muwazl, R. T. and Booth, A. J. (2003) : Strueture and eytology of the testes of Labeo victorianus (PIsees: Cyprinidae). African Zoology. 38: $119-126$.

Saad, A and Blllard, R. (1987) : Spermatozoa production and volume of semen collected after hormone stimulation in the carp. Cyprnus carplo. Aquaculture, 65: 67 - 77.

Sabat, M.; Fablana Lo Nostro; Margardda Casaderall and Marta Munoz (2009) : A Light and Electron Mlcroscoplc Study on the Organization of the Testis and the Semicystic Spermatogenesis of the Genus Scorpaena (Teleostel. Scorpaenidae) Journal of Morphology.

Santos, A. A. Matta, S. L. P. And Andrade. D. R. (1995) : Epoca e tipo de desova de lambari Ollgosarcus argenteus. Anais do Encontro Brasilelro de Ictiologia. G4-G4.

Bnntor. J. E; G.E. Padllha; O. Boncompagnl Junior; G. B. Santos; E. Rizzo \& N. Bazzoll. (2008) : oocyte growth and follicular envelope development iu the cat Iheringlehthys labrosus (SIluriformes: PImeloblbae). Tissue and Cell 38 (5): 303-310.

Schuiz, R. W.: Mentlng, S.; Bogerd, J.; Franca, L. R.; Vllela, D. A. R. and Godinho, K. P. (2005) : Sertoli cell proliferation in the adult testls- evidence from two flsh speeies belonging to different orders. Biol. Reprod. 73: 891 - 898 .

Schulz, R. W.; Lulz Renato de França; Jean-Jacques Lareyre; Florence LeGac; HeHo Chlarni-Garcla; Rafael Henrlque Nobre- ga and Takeshl Miura (2009) : Spermatogencsis in Ash. General and Comparative Endoerinology.

Selman, K., and Wallace, R. A (1989) : Cellular aspects of oocyte growth in teleosts.Zoolog. Sci. 6 211-231.

Selman, K.; Wallace, R. A. and Barr, V. (1986) : Oogenesis In Fundulus heteroclltus.IV.Yolk vestcle formation. J. Exper.Zool.. 239: 277-288.

Selman, K.; Wallace, R. A. and Player, D. (1991) : Ovary of Seahorse. Hippocampus erectus. J.Morphol., 209: 285-304.

Wallace, R. A. and Selman, K. (1981) : Cellular and dynamlc aspect of oocyte growth in teleosts. Amer. Zool., 21: 325 - 343.

Yoakim, E. G. (1971) : Seasonal varlations in the pituitary gland and gonads of the Nile catflsh (Syndontus schall) in relation to its reproductive. cycle. PD. Thesis. Faculty of Sclence. Ain Shams University.

Zak1, M. I.; Dowdar, M. N. and Abdala. A. (198Bb) : Reproductive blology of Glorlas garleplnus (Syn. lazera) Burchell (clarildac) in lake Manzalah. Egypt. II. Structure of the testes. Folia Morphologica, 43: 307-313.

Zakl, M. I.; Massoud, A. A.; Madkour, G. A. and El-Mesiry, G. E. [1996) : The cyclic changes in the pitultary gland and gonads of Siganus rivulatus from the Red Sea (Hurghada Area). J. KAU. Mar. Scl.. Vol.7, speclal Issue: Symp. Red Sea Mar. Environ. Jeddah. PP. 271-287. 


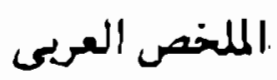

تأثير التغيرات الموسيمية على التركيب النسـيسجى للغــدد التناسـلية

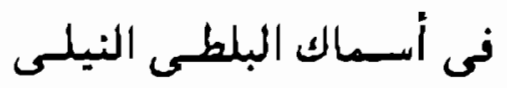

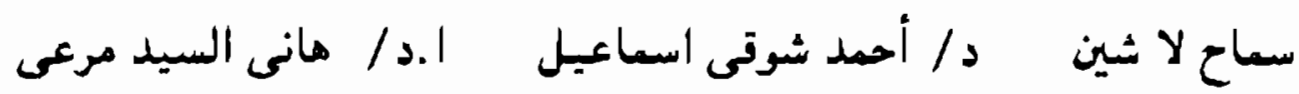

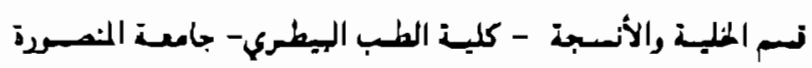

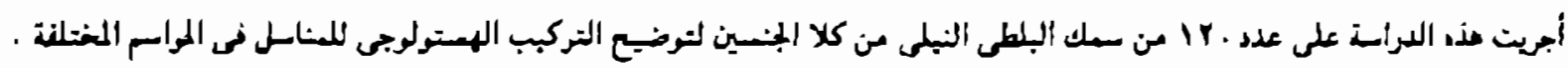
- البمبن

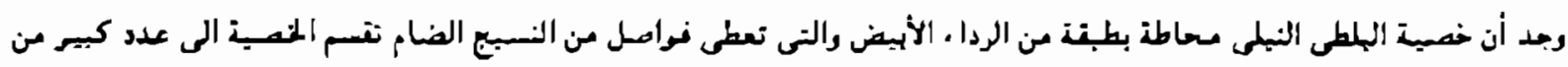

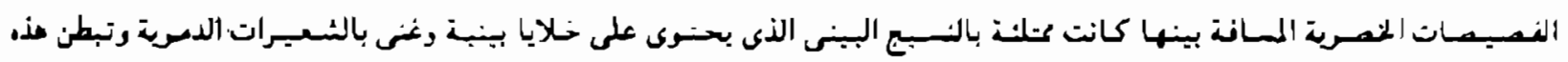

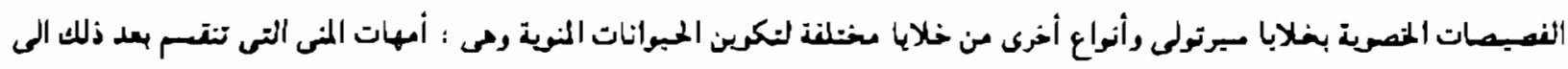

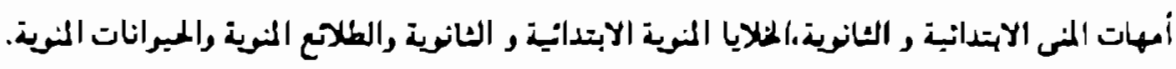

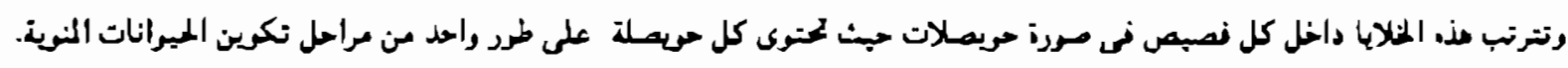

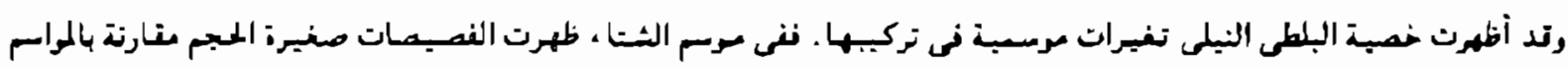

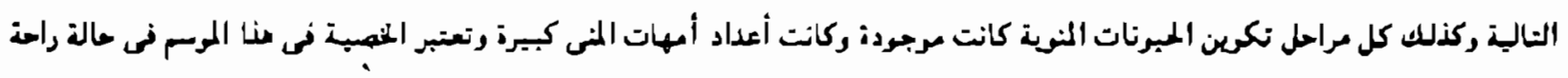
أد عدم نثاط.

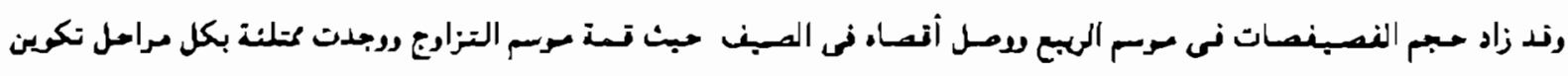

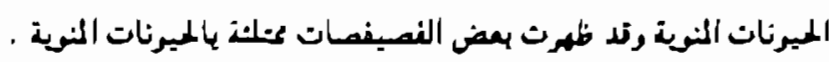

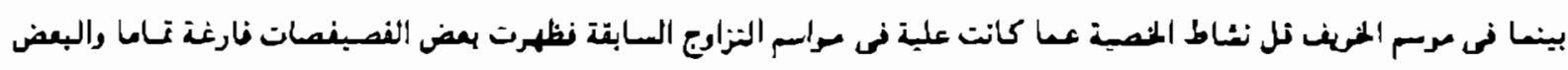
الآخر إحتوى على بعض الميرنات المنوية.

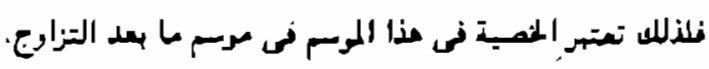

- الميضن

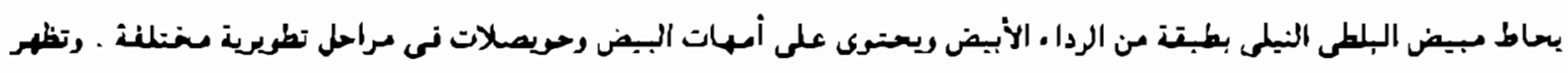

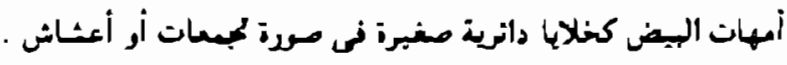


Lashen Samah; et al...

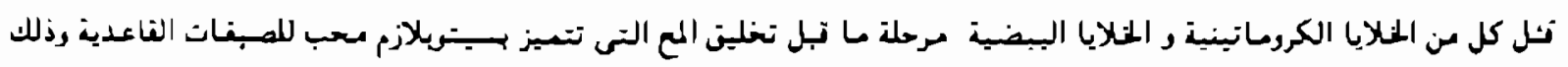

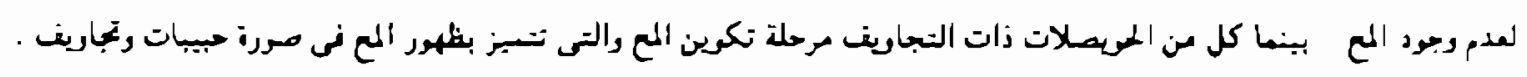

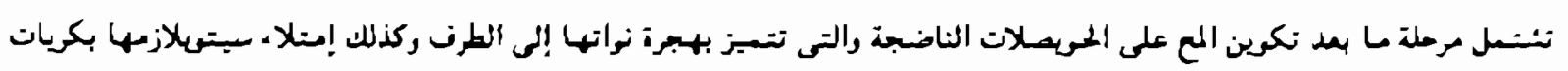
المع الكبرة: . لرجد نوع أخر من المويصلات رالثى تَيزت بتضهم خلاياها المويصلية وتدمبر معها وتد عرنت هذه المويصلات بالمويصلات المتوتة .

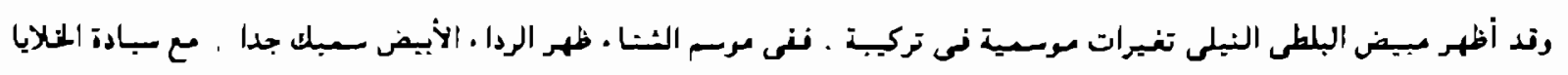

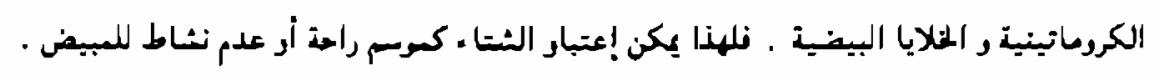

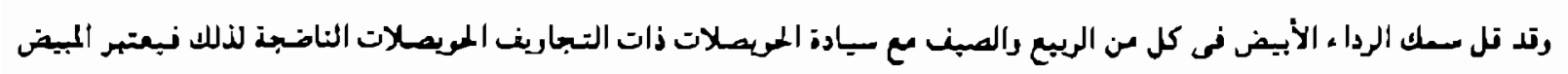

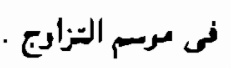

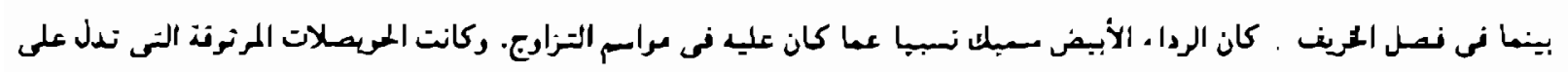

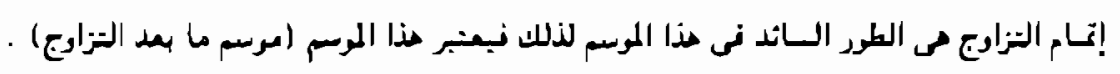

